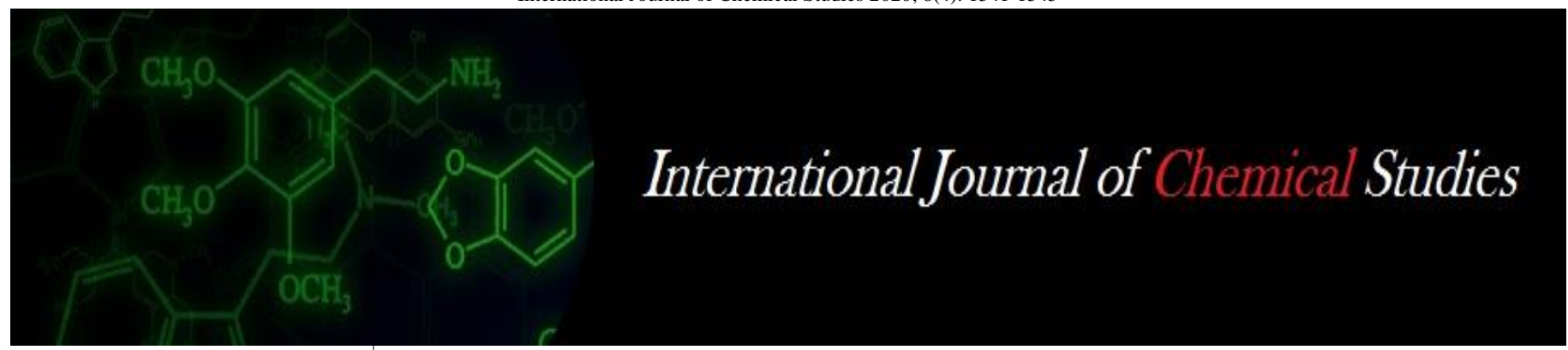

P-ISSN: 2349-8528

E-ISSN: 2321-4902

www.chemijournal.com

IJCS 2020; 8(4): 1541-1545

(C) 2020 IJCS

Received: 03-05-2020

Accepted: 08-06-2020

\section{AC Polaiah}

ICAR-Directorate of Medicinal and Aromatic Plants Research, Anand, Gujarat, India

\section{Parthvee RD}

ICAR-Directorate of Medicinal and Aromatic Plants Research, Anand, Gujarat, India

\section{Manjesh GN}

ICAR-Directorate of Medicinal and Aromatic Plants Research, Anand, Gujarat, India

\section{Thondaiman}

ICAR-Directorate of Medicinal and Aromatic Plants Research, Anand, Gujarat, India

\section{Shivakumara KT}

ICAR-Directorate of Medicinal and Aromatic Plants Research, Anand, Gujarat, India
Corresponding Author: AC Polaiah

ICAR-Directorate of Medicinal and Aromatic Plants Research, Anand, Gujarat, India

\section{Effect of presowing seed treatments on seed germination and seedling growth of sandalwood (Santalum album L.)}

\section{AC Polaiah, Parthvee RD, Manjesh GN, V Thondaiman and Shivakumara KT}

DOI: https://doi.org/10.22271/chemi.2020.v8.i40.9830

\begin{abstract}
Sandalwood (Santalum album L.) is indigenous to India and belongs to the family Santalaceae. It is a vulnerable species as listed in the Red Data Book. Sandalwood has a high demand for its highly valued essential oil and wood. The oil extracted from the heartwood of Santalum album is used as a fragrance enhancer and preparation of costly perfumes. It was strongly associated with Indian religious and culture. The seeds of sandalwood have inherent morphophysiological dormancy, low and prolonged germination and poor establishment of seedlings. To overcome this problem, a research was carried out to study the effect of $\mathrm{GA}_{3}$, cow urine, cow dung slurry and chemicals such as $\mathrm{HNO}_{3}, \mathrm{KNO}_{3}$, Thiourea and $\mathrm{H}_{2} \mathrm{SO}_{4}$ on seed germination and morphological parameters of sandalwood at ICAR-Directorate of Medicinal and Aromatic Plants Research Anand, Gujarat. It was observed that $\mathrm{GA}_{3} @ 1500 \mathrm{ppm}$ proved the best treatment for breaking the seed dormancy along with better germination and seedling growth of sandalwood. Significantly maximum seed germination percentage $(41 \%)$, collar diameter $(3.05 \mathrm{~mm})$, fresh weight of root $(0.53 \mathrm{~g})$, fresh weight of shoot $(1.06 \mathrm{~g})$, fresh weight of foliage $(2.92 \mathrm{~g})$, fresh weight of plant $(4.51 \mathrm{~g})$, root length $(11.52 \mathrm{~cm})$, shoot length $(22.42 \mathrm{~cm})$, dry weight of shoot $(0.27 \mathrm{~g})$, dry weight of root $(0.15 \mathrm{~g})$, number of leaves $(17.60)$ and dry weight of foliage $(0.32 \mathrm{~g})$ was recorded as compared to the untreated seeds and also other treatments. From this study, it can be suggested that treating Santalum album seeds with GA 3 @1500ppm gave higher germination percentage and better growth of the seedlings of sandalwood.
\end{abstract}

Keywords: Santalum album, seed dormancy, germination percentage, seedling growth

\section{Introduction}

Sandalwood (Santalum album L.) belongs to the family Santalaceae. It is native to India. It is commonly called as Indian sandalwood in English; Chandana, Hari chandana in Sanskrit; Chandan in Hindi, Bengali and Punjabi; Srigandha, Chandana in Kannada; Chandanam in Malayalam; Santhanam, Srigandhara in Tamil; Chandanamu, Hari chandanam in Telugu, Boga Chandon in Assamese; Cha-chandan in Manipuri; Chandono, Gondassaro in Oriya; Sukahad and Suket in Gujarati. It is strongly associated with Indian religion and culture. Despite the Sandalwood has been distributed all over the country, $90 \%$ of the population of sandalwood found in Karnataka and Tamil Nadu covering approximately an area of 8300sq.kms (Arun Kumar et al. 2016) ${ }^{[3]}$. It grows well in a wide range of soils and climatic conditions of tropical and subtropical areas of India. India is the leading producer of sandalwood oil for perfumery and pharmaceutical industries. It is known as 'Royal Tree' as mentioned in 1792 edict by Tipu Sultan, the ruler of the Mysore kingdom. According to IUCN 2000, it is considered as vulnerable species in nature. It is found in countries like Australia, Indonesia, Japan, Belgium, China, Cambodia, Madagaskar, Germany, Holland, Norway, Russia, Switzerland and the United States. Sandalwood is a slow-growing and small to medium-sized semi-parasitic tree with drooping branches. The leaves are opposite, flowers are hermaphrodite and the inflorescence is cymose type. The fruits are small globose and berry type. The outer sapwood is white and odourless whereas the inner heartwood is scented. Chandan tree is considered a sattvic tree. The active ingredients present in sandalwood oil are $\alpha$ Santalol and $\beta$ Santalol. The $\beta$ Santalol is responsible for $90 \%$ of its characteristic odoriferous nature. The value of sandalwood oil is high where the $\beta$-santalol content is high in the oil. 
The wood of sandal had both medicinal and aromatic properties. Sandalwood is mainly used as coolant. It is used as disinfectant in genitourinary and bronchial tract, diuretic, expectorant and stimulant. It has a sedative effect and astringent activity. It is used for purifying blood and memory improvement. It is also used for bleeding piles, urticaria, eye infection and vomiting. The essential oil of sandalwood is used for skin problems like pimples, prickly heat, skin eruptions, itching, swelling and rashes. It is considered mainly as a cosmetic material. Apart from its medicinal uses its wood is also used for making wood carving articles. Many items like rosary from seeds, soaps, perfumes, incense stick and powder etc. It has an important place in Hindu religious ceremonies. In India, the natural plantations of sandalwood is gradually diminishing due to changes in the land use pattern, habitat destruction, illegal felling and theft of plantations (Arun Kumar et al.,2012) ${ }^{[2]}$. In addition to that the natural calamity such as fire, drought and floods and grazing of the seed by animals also causes a rapid decline in nature. Seed dormancy is maximum in sandalwood seeds (Doran et al., $2005)^{[5]}$. Seed dormancy is the most limiting factor for seed germination and thus it causes prolongation in the seed germination. The seeds of sandalwood are impermeable to water and oxygen thus inhibits the germination of the seed. Various other factors also cause seed dormancy like impermeable seed coats, mechanically resistant seed coats, rudimentary and physiological immature embryo, morphologically mature and physiological immature embryos (Das and Tah, 2013) ${ }^{[4]}$. Hence, there is a need to enhance the seed germination by breaking the seed dormancy through various presowing seed treatments. Different methods using conventional vegetative plant propagation methods like semihardwood cuttings and air layering are not successful. Hence, the present experiment has been taken up to study the effect of presowing seed treatments of sandalwood by various chemicals to break the seed dormancy and ensure superior quality seedlings, and supply of quality planting materials to promote the cultivation of sandalwood to meet the demand from the industry.

\section{Materials and Methods}

The experiment was conducted at ICAR-Directorate of Medicinal and Aromatic Plants Research, Anand during the year 2018-19. The matured ripe and uniform fruits of sandalwood were collected from the mother plant in the nursery at Directorate of Medicinal and Aromatic Plants Research, Boriavi, Anand. The fruits were soaked in water and rubbed with a hard surface to remove the pulp. The depulped seeds were dried in the shade. Before sowing, the seeds were treated with fungicide to control fungal attack. The sandalwood seeds were subjected into 11 different treatments comprises $\mathrm{T}_{1}$-Control, $\mathrm{T}_{2}$-Water Soaking, $\mathrm{T}_{3}$-Cow urine, $\mathrm{T}_{4}$ Cow dung slurry, $\mathrm{T}_{5}-\mathrm{HNO}_{3}, \mathrm{~T}_{6}-\mathrm{KNO}_{3}, \mathrm{~T}_{7}$-Thiourea, $\mathrm{T}_{8}-\mathrm{GA}_{3}$ 500ppm, $\mathrm{T}_{9}-\mathrm{GA}_{3} 1000 \mathrm{ppm}, \mathrm{T}_{10}-\mathrm{GA}_{3} 1500 \mathrm{ppm}$ and $\mathrm{T}_{11}$-conc. $\mathrm{H}_{2} \mathrm{SO}_{4}$ to break the seed dormancy and to enhance seed germination. The seeds were sown without any treatment as control. For the treatment of conc. $\mathrm{H}_{2} \mathrm{SO}_{4}$, the seeds were kept for 1 minute in conc. $\mathrm{H}_{2} \mathrm{SO}_{4}$ and then washed with running tap water to remove the traces of acid from the seeds whereas in other treatments the seeds were soaked for 24 hours in the water, cow urine, cow dung slurry, $\mathrm{HNO}_{3}, \mathrm{KNO}_{3}$, Thiourea, $\mathrm{GA}_{3}$ at 500, 1000 and $1500 \mathrm{ppm}$. Further, the seeds were sown in polythene bags containing a mixture of sand, soil and FYM of 1:2:1 ratio with Cajanus cajan as a host plant in the nursery under the shade condition. The experiment was laid out in a randomized block design with three replications. In each replication, 100 seeds were sown. The observations were recorded on five randomly selected seedlings at 12 months after sowing from each treatment. The observations namely, germination percentage, collar diameter, shoot length, root length, fresh weight of root, fresh weight of shoot, fresh weight of foliage, fresh weight of the plant, dry weight of root, dry weight of shoot and number of leaves. The collar diameter was measured with the help of digital vernier calliper and recorded in millimetre. The length of the shoot was measured from collar region of the shoot to the apex region while the root length was measured from the collar region of root to the root tip and the data was expressed in centimetres. The fresh weight of plant, root, shoot and foliage was recorded from the freshly collected seedlings and expressed in grams. The dry weight of plant, root, shoot and foliage were recorded and expressed in grams. The number of leaves was counted on a visual basis and expressed in numbers. The germination percentage was calculated as:

Germination percentage $=\frac{\text { seeds germinated }}{\text { Total no. seeds }} \times 100$

The data were analyzed using the analysis of variance by Web-based Agricultural Statistics Package (WASP) version 2 software developed by ICAR-Research Complex for Goa, India.

\section{Results and Discussion}

The significant results were recorded for germination percentage and seedling growth parameters of the sandalwood such as collar diameter $(\mathrm{mm})$, fresh weight of root $(\mathrm{g})$, fresh weight of shoot $(\mathrm{g})$, fresh weight of foliage $(\mathrm{g})$, fresh weight of plant $(\mathrm{g})$, root length $(\mathrm{cm})$, shoot length $(\mathrm{cm})$, dry weight of root $(\mathrm{g})$, dry weight of shoot $(\mathrm{g})$, dry weight of foliage $(\mathrm{g})$ and number of leaves by different pre-sowing seed treatments and the results were shown in table 1 and table 2.

\section{Effect on seed germination}

The significant effect of various pre-sowing seed treatments on seed germination and seedling growth of sandalwood were recorded. Among the treatments, it was observed that the seeds treated with $\mathrm{GA}_{3} 1500 \mathrm{ppm}$ showed significantly highest germination percentage $(41.00 \%)$ than the control $(13.33 \%)$ whereas the lowest germination percentage was noticed where the seeds were treated with conc. $\mathrm{H}_{2} \mathrm{SO}_{4}(6.66 \%)$ and it was due to damage caused to the seeds or embryo (Wang et al. $2007)^{[20]}$. Highest germination might be due to the effect of $\mathrm{GA}_{3}$ in cytological activities. The cytological enzyme leads to the increase in the plasticity of the cell wall and the absorption of water. $\mathrm{GA}_{3}$ releases the seeds from dormancy by promoting protein synthesis, elongation of coleoptiles and production of ethylene (Stewart and Freebairn, 1969) ${ }^{[17]}$. The similar results were reported by Nagaveni et al. (1989) ${ }^{[9]}$ the sandalwood seeds treated with different growth hormones and chemicals and found that $\mathrm{GA}_{3}$ treated seeds exhibited high germination percentage under field condition. Hence, $\mathrm{GA}_{3}$ had a significant effect on breaking the seed dormancy and the germination of the seed. The results were by Palani et al., (1996) ${ }^{[10]}$ reported the effects of pre-sowing treatments in Albizia lebbeck. The results were in line with Muruganandam et al., (2019) ${ }^{[8]}$ reported a high percentage of germination $(56.55 \%)$ of the Gloriosa superba seeds treated with the $\mathrm{GA}_{3}$ and they found at lower concertation $200 \mathrm{ppm}$ compared to 
our study. The results of our work are similar to Hussain and Jha (2014) ${ }^{[6]}$ who observed that improved seed germination percentage in Rauvolfia serpentina (48.65\%) and $R$. tetraphylla $(56.66 \%)$ seeds treated with the $\mathrm{GA}_{3}$.

\section{Morphological attributes}

Significantly maximum collar diameter was recorded in the treatment of cow urine $(3.56 \mathrm{~mm})$ followed by $\mathrm{GA}_{3}$ @ $1500 \mathrm{ppm}(3.05 \mathrm{~mm})$ than the control $(1.57 \mathrm{~mm})$. The maximum collar diameter was due to nutrients present in the cow urine and cell division and cell elongation due to gibberellic acid in the collar region (Shanmugavelu, 1966) ${ }^{[16]}$. It can be said that the better and rapid growth of the seedlings might be due to the presence of growth promoting hormones like auxin and also the presence of nutrients in the cow urine. (Swamy et al., 1999 and Mishra et al., 2002) [7, 18]. The significantly maximum fresh weight of root $(0.53 \mathrm{~g})$ was observed the sandal seeds treated with $\mathrm{GA}_{3} 1500 \mathrm{ppm}$. The fresh weight of shoot was found significantly maximum in the treatment of $\mathrm{GA}_{3} 1500 \mathrm{ppm}(1.06 \mathrm{~g})$ as compared to the control $(0.52 \mathrm{~g})$. The data on fresh weight of foliage showed significantly highest value $(2.92 \mathrm{~g})$ in the treatment of $\mathrm{GA}_{3}$ $1500 \mathrm{ppm}$. The fresh weight of plant was highest in the treatment $\mathrm{GA}_{3} 1500 \mathrm{ppm}(4.51 \mathrm{~g})$ than the untreated seed $(2.06 \mathrm{~g})$. Among the treatments, $\mathrm{GA}_{3}$ with $1500 \mathrm{ppm}$ had significant effect on seed germination and also seedling attributes. Seed germination is promoted by gibberellic acid $\left(\mathrm{GA}_{3}\right)$ (Rehman and Park, 2000) ${ }^{[14]}$. Gibberellic acid is known to induce the expression of genes encoding enzymes that mobilize the reserved food material stored in the endosperm which includes starch, protein and lipids. This helps in increasing the biological yield of the plant. The overall increase in the growth of the plant is due to gibberellic acid which leads to the increase in rate of photosynthesis. The increased rate of photosynthesis helps in the higher accumulation of photosynthates within the cell and the plant and resulted in higher fresh weight and dry weight of root, shoot and plant (Patel et al., 2018) ${ }^{[11]}$.

Significantly highest root length $(12.60 \mathrm{~cm})$ was recorded when the seeds treated with cow urine over the control $(8.83 \mathrm{~cm})$ and it was statistically at par with $\mathrm{GA}_{3} 500 \mathrm{ppm}$ $(11.76 \mathrm{~cm})$, and $\mathrm{GA}_{3} 1500 \mathrm{ppm}(11.52 \mathrm{~cm})$, and $\mathrm{KNO}_{3}$ $(11.50 \mathrm{~cm})$. The minimum root length was observed in the treatment of thiourea $(3.50 \mathrm{~cm})$. The shoot length was found highest $(22.42 \mathrm{~cm})$ in the treatment $\mathrm{GA}_{3} 1500 \mathrm{ppm}$ compared to the untreated seeds $(18.58 \mathrm{~cm})$ and it was on par with the $\mathrm{GA}_{3} 500 \mathrm{ppm}(21.32 \mathrm{~cm})$. Significantly the least shoot length was observed in conc. $\mathrm{H}_{2} \mathrm{SO}_{4}(12.28 \mathrm{~cm})$. The increasing of shoot length and root length is due to the treatment of plant growth promoting hormone gibberellic acid. The most characteristic effect of gibberellic acid on shoot growth is increased inter-node extension, increased leaf growth and enhanced apical dominance. Plant hormone like gibberellic acid plays an important role in plant growth and development (Zhang et al., 2014) ${ }^{[21]}$. The cytological basis of gibberellic acid involves the promotion of cell elongation and cell division ultimately increasing the length of root and shoot and also the plant height (Achard et al., 2009) ${ }^{[1]}$.

The dry weight of shoot was found significantly maximum in $\mathrm{GA}_{3}$ 1500ppm (0.27g) which was followed by with the treatment of cowdung slurry $(0.22 \mathrm{~g})$. The least dry weight of shoot was found in water soaking and cow urine treatment $(0.07 \mathrm{~g})$. Similarly, the dry weight of root was found highest in $\mathrm{GA}_{3} 1500 \mathrm{ppm}(0.15 \mathrm{~g})$. The dry weight of root was found minimum in water soaking $(0.01 \mathrm{~g})$. The numbers of leaves were produced maximum in the treatment $\mathrm{GA}_{3} 1500 \mathrm{ppm}$ (17.60) while the minimum numbers of leaves were noticed in the treatment of water soaking (1.66). The treatment of $\mathrm{GA}_{3}$ $1500 \mathrm{ppm}$ was on par with the treatment cow dung slurry (14.55) and thiourea (14.40). The numbers of leaves are more because of the higher growth of the seedlings and also due to the activity of $\mathrm{GA}_{3}$ at the apical region. These results might be due to more synthesis of nucleoprotein responsible for increasing the leaf initiation and as a result of this more number of leaves was produced (Sen and Ghunti, 1976) ${ }^{[15]}$. It was observed that soaking of seeds in gibberellic acid is one of the most successful methods for accelerating the germination of the seeds of sandalwood (Rai, 1990 and Tennakoon et al., 2000) ${ }^{[12,19]}$. Similar results have been reported by Raviraja Shetty et al. (2016) ${ }^{[13]}$ in Celastrus paniculatus a willd a threatened medicinal plant where the seeds treated with lower concentration of $\mathrm{GA}_{3}$ i.e. $400 \mathrm{ppm}$.

\section{Conclusion}

From this study it could be concluded that the sandal wood seeds were treated with $\mathrm{GA}_{3}$ 1500ppm germinated faster and also gave better growth performances. It was observed that $\mathrm{GA}_{3}$ 1500ppm recorded maximum germination percentage, fresh weight of root, fresh weight of shoot, fresh weight of foliage, fresh weight of plant, shoot length, dry weight of shoot, dry weight of root, dry weight of foliage and number of leaves. Thus, it can be suggested that $\mathrm{GA}_{3} 1500 \mathrm{ppm}$ is the best method to break the seed dormancy as it gave the maximum seed germination percentage and seedling growth to supply quality planting materials for the cultivation of sandalwood.

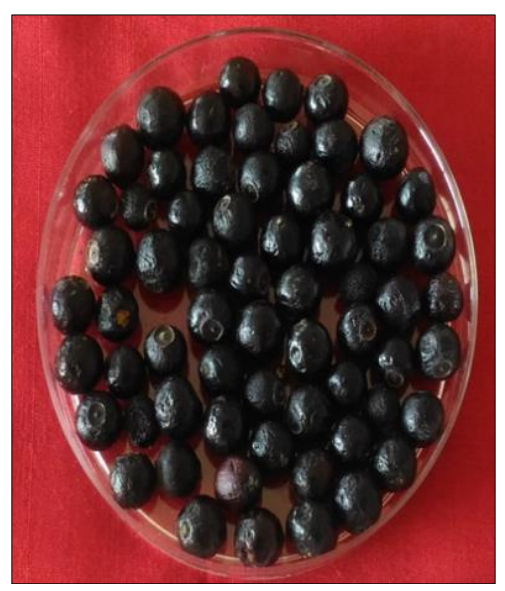

Fig 1: Sandalwood seeds

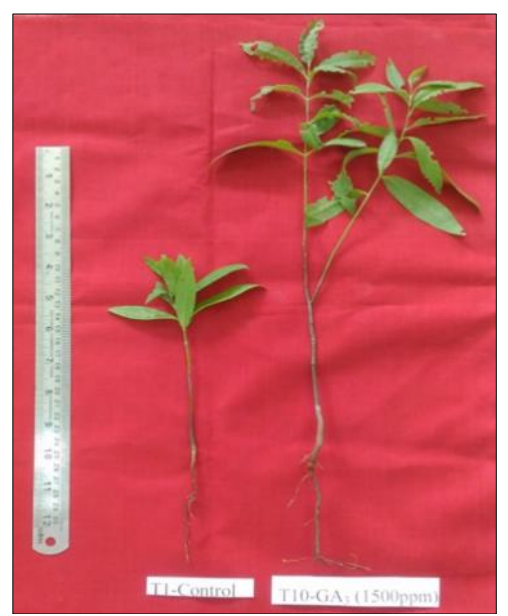

Fig 2: Seedlings 


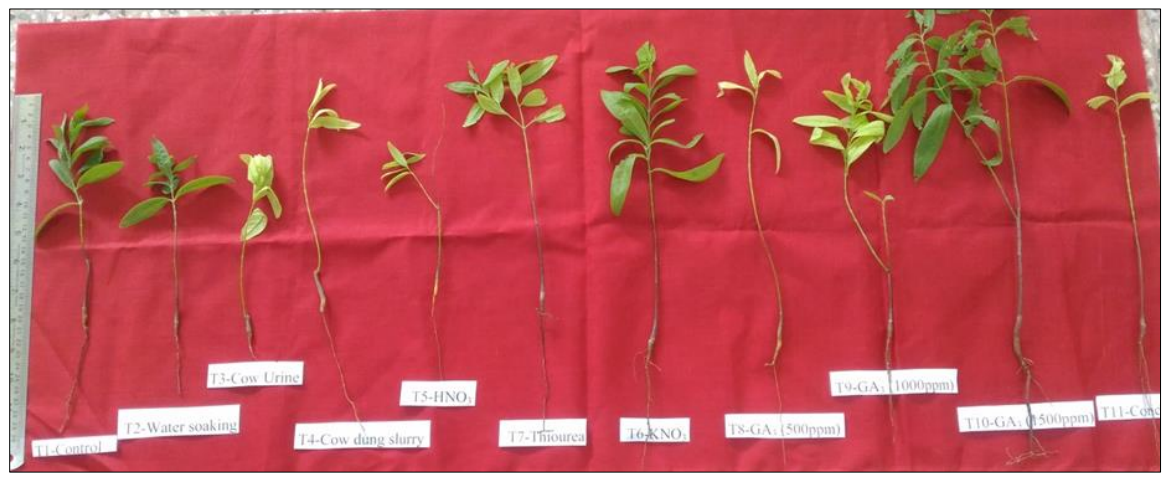

Fig 3: Effect of various pre-sowing seed treatments on germination and growth of sandalwood seedlings

Table 1: Effect of pre-sowing treatments on germination percentage, collar diameter, fresh weight of root, fresh weight of shoot, fresh weight of foliage, fresh weight of plant of Sandal wood

\begin{tabular}{|c|c|c|c|c|c|c|}
\hline Treatment & $\begin{array}{c}\text { Germination } \\
\text { percentage }(\%)\end{array}$ & $\begin{array}{c}\text { Collar } \\
\text { diameter }(\mathbf{m m}) \\
\end{array}$ & $\begin{array}{c}\text { Fresh weight of } \\
\operatorname{root}(\mathrm{g})\end{array}$ & $\begin{array}{l}\text { Fresh weight of } \\
\text { shoot (g) }\end{array}$ & $\begin{array}{c}\text { Fresh weight of } \\
\text { foliage (g) }\end{array}$ & $\begin{array}{c}\text { Fresh weight of } \\
\text { plant (g) }\end{array}$ \\
\hline T1-Control & 13.33 & 1.57 & 0.28 & 0.52 & 1.25 & 2.06 \\
\hline T2-Water soaking & 10.00 & 1.81 & 0.05 & 0.24 & 0.20 & 0.50 \\
\hline T3-Cow urine & 14.66 & 3.56 & 0.14 & 0.22 & 0.43 & 0.80 \\
\hline T4-Cow dung slurry & 8.00 & 2.89 & 0.11 & 0.37 & 0.18 & 0.67 \\
\hline $\mathrm{T} 5-\mathrm{HNO}_{3}$ & 17.66 & 1.78 & 0.07 & 0.25 & 0.14 & 0.39 \\
\hline T6- $\mathrm{KNO}_{3}$ & 14.66 & 2.54 & 0.17 & 0.56 & 1.05 & 1.79 \\
\hline T7-Thiourea & 17.00 & 2.30 & 0.23 & 0.65 & 1.15 & 2.04 \\
\hline T8-GA 3 @500ppm & 18.66 & 1.36 & 0.07 & 0.35 & 0.27 & 0.55 \\
\hline T9-GA $3 @ 1000 p p m$ & 22.66 & 1.31 & 0.17 & 0.39 & 0.47 & 1.08 \\
\hline T10-GA 3 @1500ppm & 41.00 & 3.05 & 0.53 & 1.06 & 2.92 & 4.51 \\
\hline T11-Conc. $\mathrm{H}_{2} \mathrm{SO}_{4}$ & 6.66 & 2.79 & 0.13 & 0.29 & 0.12 & 0.54 \\
\hline S.Em \pm & 1.64 & 0.13 & 0.02 & 0.04 & 0.14 & 0.20 \\
\hline C.D. (0.05) & 5.90 & 0.34 & 0.05 & 0.10 & 0.15 & 0.18 \\
\hline $\mathrm{CV} \%$ & 20.69 & 9.12 & 17.58 & 13.64 & 12.33 & 8.03 \\
\hline
\end{tabular}

Table 2: Effect of pre-sowing treatments on root length, shoot length, dry weight of shoot, dry weight of root, number of leaves and dry weight of foliage of sandalwood

\begin{tabular}{|c|c|c|c|c|c|c|}
\hline Treatment & $\begin{array}{c}\text { Root length } \\
\text { (cm) }\end{array}$ & $\begin{array}{c}\text { Shoot length } \\
\text { (cm) }\end{array}$ & Dry weight of shoot (g) & Dry weight of root $(\mathrm{g})$ & Number of leavesI & Dry weight of foliage (g) \\
\hline T1-Control & 8.83 & 18.58 & 0.12 & 0.04 & 6.58 & 0.04 \\
\hline T2-Water soaking & 7.43 & 12.36 & 0.07 & 0.01 & 1.66 & 0.05 \\
\hline T3-Cow urine & 12.60 & 14.30 & 0.07 & 0.04 & 5.50 & 0.09 \\
\hline T4-Cow dung slurry & 4.65 & 15.51 & 0.22 & 0.04 & 14.55 & 0.29 \\
\hline $\mathrm{T} 5-\mathrm{HNO}_{3}$ & 6.85 & 15.55 & 0.10 & 0.03 & 6.66 & 0.03 \\
\hline T6-KNO3 & 11.50 & 18.85 & 0.21 & 0.09 & 10.50 & 0.20 \\
\hline T7-Thiourea & 3.50 & 18.36 & 0.19 & 0.09 & 14.40 & 0.19 \\
\hline T8-GA 3 @500ppm & 11.76 & 21.32 & 0.15 & 0.12 & 8.00 & 0.07 \\
\hline T9-GA 3 @1000ppm & 7.80 & 16.35 & 0.16 & 0.08 & 11.50 & 0.10 \\
\hline T10-GA3@ 1500ppm & 11.52 & 22.42 & 0.27 & 0.15 & 17.60 & 0.32 \\
\hline T11-Conc. $\mathrm{H}_{2} \mathrm{SO}_{4}$ & 6.16 & 12.28 & 0.12 & 0.05 & 4.41 & 0.03 \\
\hline S.Em \pm & 0.54 & 0.70 & 0.01 & 0.00 & 0.85 & 0.01 \\
\hline C.D. (0.05) & 1.75 & 5.14 & 0.03 & 0.02 & 2.66 & 0.02 \\
\hline CV\% & 12.21 & 17.85 & 13.39 & 20.05 & 16.97 & 9.06 \\
\hline
\end{tabular}

\section{Acknowledgement}

The authors are thankful to Director, ICAR-Directorate of Medicinal and Aromatic Plants Research, Anand, Gujarat.

\section{References}

1. Achard P, Gusti A, Cheminant S, Alioua M, Dhondt S, Coppens F. Gibberellin signaling controls cell proliferation rate in Arabidopsis. Current Biology. 2009; 19:1188-1193.

2. Arun Kumar AN, Geeta Joshi, Mohan Ram HY. Sandalwood: history uses and present status and the future. Current Science. 2012; 103(12):1408-1416.
3. Arun Kumar AN, Geeta Joshi, Rekha Warrier R. Know your trees: Santalum album (Indian sandal wood). Envis Newsletter, Van Vigyan. 2016; 2(4):2-11.

4. Das SD, Tah J. Effect of $\mathrm{GA}_{3}$ on seed germination of sandal (Santalum album L.). International Journal of Current Science. 2013; 8:79-84.

5. Doran JC, Thomson L, Brophy JJ, Goldsack B, Bulai P, Faka'osi T. Variation in heartwood oil composition of young sandalwood trees in the south Pacific (Santalumyasi, S. album and F1 hybrids in Fiji, and S.yasiin Tonga and Niue). Sandalwood Research Newsletter. 2005; 20:3-7. 
6. Hussain A, Jha D K. Seed germination improvement in two threatened medicinal plants. Current Agricultural Research Journal. 2014; 2(2):131-136.

7. Mishra SK, Virender S, Pareek SV. Standardization of propagation techniques in asparagus. Annals of Agricultural Research. 2002; 23(4):608-610.

8. Muruganandam C, Kader Mohideen M, Bhararkumar TR. Studies on the effect of certain chemicals and bio regulators on germination and seedling growth in glorilily (Gloriosa superba L.) Plant Archives. 2019; 19(2):24952500 .

9. Nagaveni HC, Ananthapadmanabha HS, Rai SN. Effect of different chemicals on germination of sanadal seeds. Myforest. 1989; 25:311-313.

10. Palani M, Dasthagir MG, Kumaran K, Jerlin R. Effect of presowing treatments on growth attributes of Albizia lebbeck L Benth. Annals of Forestry. 1996; 4(1): 85-88.

11. Patel HS, Tandel MB, Prajapati VM, Amlani MH, Prajapati DH. Effect of different pre-sowing treatments on germination of Red sanders (Pterocarpus santalinus L. f.) in net house condition. International Journal of Chemical Studies. 2018; 6(2):876-879.

12. Rai SN. Status and cultivation of sandalwood in India. Proceedings of the symposium on sandalwood in the Pacific, April 9-11, 1990, Honolulu-Hawaii, 1990, 66-71.

13. Raviraja Shetty G, Poojitha KG, Souravi K, Rajasekharan PE. Seed germination studies in Celastrus paniculatus Willd: A threated medicinal a plant. International Journal of Applied and Agricultural Research. 2016; 11(1):51-56.

14. Rehman S, Park IH. Effect of scarification, gibberellic acid and chilling on the germination of golden rain-tree (Koelreuteria paniculata Laxm) seeds. Scientia Horticulturae. 2000; 85:319-324.

15. Sen SK, Ghunti P. Effect of pre-sowing seed treatment on the germination and seedling growth in papaya. Orissa Journal of Horticulture. 1976; 4:38-43.

16. Shanmugavelu KG. Studies on the effect of plant growth regulator on the seedling of some tree plant species. South Indian Horticulture. 1966; 14:24-25.

17. Stewart ER, Freebairn HT. Ethylene, seed germination and epinasty. Plant Physiology. 1969; 44:955-958.

18. Swamy GSK, Patil PB, Athani SI, Prabhushankar DS. Effect of organic and inorganic substances on germination of Jamun (Syzygium cumini) seeds. Advances in Agriculture in India. 1999; 11:89-91.

19. Tennekoon KU, Ekanayake SP, Etampawala ERLB. An overview of Santalum album research in SriLanka. Sandalwood Research Newsletter. 2000; 11:1-4.

20. Wang YR, Hanson J, Mariam YW. Effect of sulphuric acid pretreatment on breaking hard seed dormancy in diverse accessions of five wild Vigna species. Seed Science and Technology. 2007; 35:550-559.

21. Zhang Y, Zhang S, Lin J, Wang Y, Fang X. Research progress on cloning and functional analysis of plant height genes in rice (Oryza sativa L.). Chinese Agricultural Science Bulletin. 2014; 30:78-89. 